\title{
Foreign Body in Genitourinary Tract
}

National Cancer Institute

\section{Source}

National Cancer Institute. Foreign Body in Genitourinary Tract. NCI Thesaurus. Code C35252.

Extraneous material located within the genital and urinary organs. 